\title{
Tax, price and cigarette smoking: evidence from the tobacco documents and implications for tobacco company marketing strategies
}

\section{F J Chaloupka, K M Cummings, CP Morley, JK Horan}

Tobacco Control 2002; 11 (Suppl I):i62-i72

See end of article for authors' affiliations

Correspondence to: F J Chaloupka, Department of Economics (m/c 144), University of Illinois at Chicago, 601 South Morgan Street, Chicago, IL 60607-7121, USA; fjc@uic.edu
Objective: To examine tobacco company documents to determine what the companies knew about the impact of cigarette prices on smoking among youth, young adults, and adults, and to evaluate how this understanding affected their pricing and price related marketing strategies.

Methods: Data for this study come from tobacco industry documents contained in the Youth and Marketing database created by the Roswell Park Cancer Institute and available through http:// roswell.tobaccodocuments.org, supplemented with documents obtained from http://www. tobaccodocuments.org.

Results: Tobacco company documents provide clear evidence on the impact of cigarette prices on cigarette smoking, describing how tax related and other price increases lead to significant reductions in smoking, particularly among young persons. This information was very important in developing the industry's pricing strategies, including the development of lower price branded generics and the pass through of cigarette excise tax increases, and in developing a variety of price related marketing efforts, including multi-pack discounts, couponing, and others.

Conclusions: Pricing and price related promotions are among the most important marketing tools employed by tobacco companies. Future tobacco control efforts that aim to raise prices and limit price related marketing efforts are likely to be important in achieving reductions in tobacco use and the public health toll caused by tobacco.
$\mathrm{P}$ ricing has long been one of the most important marketing strategies employed by tobacco companies in the USA and around the world. In the USA, the rise of American Tobacco Company was in large part due to the aggressive pricing strategies pursued by James Duke, made possible by the cost advantages he achieved from being the first cigarette producer to move from hand rolling of cigarettes to mass production using the Bonsack cigarette machine, invented in $1880 .{ }^{1}$ This allowed Duke to cut prices for his brands to half of the cost of the typical hand rolled cigarette, put a much larger share of the revenues generated from cigarette sales into an aggressive advertising and promotion campaign, and still earn him significant profits. Using this combination of aggressive pricing and advertising, along with a variety of other business strategies that would soon become illegal under the emerging US antitrust laws, Duke forced his competitors to either join him or drove them out of the market. In less than a decade, Duke's consolidation of the US cigarette industry created the American Tobacco Company, with control over more than $90 \%$ of the cigarette market. During this time, in large part because of these much lower prices and more aggressive marketing efforts, per capita cigarette consumption in the USA rose from less than one half cigarette per year in 1870 to 35 cigarettes per year in 1890. Cigarettes, however, were a relatively small part of the US tobacco markets at the time.

The profits resulting from this monopoly power in the cigarette markets led American Tobacco to move into the markets for other tobacco products, subsidising the same types of aggressive pricing and marketing strategies that eventually gained it a significant share of these markets as well. Perhaps most important among these strategies were the "fighting brands"-very low priced cigarettes and other tobacco products, including some priced below manufacturing coststhat were used to drive competitors from the market. ${ }^{1}$ These and other anti-competitive practices eventually led to the 1911 breakup of American Tobacco Company under the Sherman Antitrust Act. Four tobacco giants emerged from the breakup: American Tobacco Company (ATC), RJ Reynolds Tobacco
Company (RJR), Liggett \& Myers Tobacco Company (L\&M), and P Lorillard Company. Over the next two decades, these companies primarily competed through new product development (for example, Camel cigarettes containing a premium blend of tobacco sold at a premium price $^{2}$ ), advertising, including ads targeting women (for example, "Reach for a Lucky instead of a sweet") and other efforts. Because of their successful marketing strategies, three of these four companies came to dominate the US cigarette markets, with about $90 \%$ of the US markets controlled by RJR (41.6\%), L\&M (26.6\%), and ATC (21.2\%) by $1925 .{ }^{3}$ In addition, some strategies that helped grow the markets in the aftermath of the breakup were clearly price based, such as the distribution of free cigarettes to American soldiers during the first world war. By 1930, annual per capita consumption had grown to 977 cigarettes and cigarettes had become the dominant form of tobacco use.

After a relatively short learning period, pricing in US cigarette markets during the 1920s became characterised by price leadership, with one firm - typically RJR-announcing a change in prices for its brands that was almost immediately followed by identical changes in the prices of other brands. This led to cigarette prices well above the level that would exist in more competitive markets, generating profits for cigarette producers that were much greater than those earned in other industries. ${ }^{4}$ These high prices ( 15 cents per pack for most brands by 1931) and profits, along with the economic hardship of the depression era, however, created an opportunity for new firms to enter the market or for existing small firms to significantly expand their presence by competing on price. Several did so with their "10 cent brands". While not extensively advertised, these discount brands gained nearly a

Abbreviations: ATC, American Tobacco Company (ATC); B\&W, Brown \& Williamson; L\&M, Liggett \& Myers Tobacco Company; NBER, National Bureau of Economic Research; RJR, RJ Reynolds Tobacco Company; YAS, young adult smokers 
quarter of the market by 1932, before the big three responded by cutting their prices, behaviour contributing to their 1941 conviction for violating the Sherman Antitrust Act. ${ }^{3}$ While many of the new companies eventually disappeared, two of them-Philip Morris and Brown \& Williamson (British American Tobacco's US subsidiary (B\&W))-would become significant players in the US markets.

The next several decades were characterised by relative stability in cigarette prices, with little price competition among firms in the industry. During this time, an increasing number of states began taxing cigarettes, with the number of taxing states (including the District of Columbia) rising from 14 in 1932 to 50 by 1966 . However, these taxes were typically very low, were primarily used to generate revenue, and were raised infrequently. Similarly, federal cigarette taxes were modest and stable over time, with the increases during this period used to raise revenues during wartime. In 1951, the federal tax was set at 8 cents per pack - the level at which it would remain for more than 30 years.

With the release of the first scientific studies on the health risks from smoking in the 1950s, and the subsequent 1964 Surgeon General's report, the landscape began to change. Many states began increasing cigarette excise taxes in an apparent effort to reduce smoking and its consequences. ${ }^{5}$ Economists and others began producing studies documenting the impact of cigarette taxes and prices on smoking, particularly among youth and young adults. ${ }^{5}$ These findings led to growing pressure from public health groups for further increases in state taxes and increased federal cigarette taxes. Eventually, the federal cigarette tax was doubled to 16 cents per pack on 1 January 1 1983. Numerous states did the same during the 1980s and early 1990s, with some increases of $200 \%$ or more.

The changes in cigarette taxes and the price changes they induced were of significant concern to the cigarette companies. Likewise, they paid close attention to the academic and other research that was emerging on the impact of prices and taxes on smoking, in addition to conducting their own research on these issues. The internal tobacco company memoranda, reports, and other documents released as a result of the various lawsuits and settlements of the past several years provide a unique opportunity to add to our understanding of these matters. The documents include discussions of the industry's own estimates of the impact of price on cigarette smoking, particularly among key population subgroups like young persons. They contain fascinating reviews of the academic studies examining these issues. Perhaps most interestingly, they provide an intriguing look at how the industry uses the range of price based marketing strategies available to it to counter the effects of higher taxes and more comprehensive tobacco control efforts. This paper contains an initial look at the range of issues related to price and tax contained in these documents.

\section{METHODOLOGY}

The procurement of tobacco industry documents for this study relied upon the previously constructed Youth and Marketing database, created by Roswell Park Cancer Institute and available through http://roswell.tobaccodocuments.org. The search methodology for this collection is described elsewhere in this issue. ${ }^{6}$ Documents discussing pricing were included in this collection, since price level is a component of marketing strategy.

The term "pric*" was entered into the Youth and Marketing search engine, returning 288 results. The results of this search were then evaluated for relevancy. Document citations containing the surname "Price" were included in the search results, and were removed from consideration for this study. The relevant documents were added to the "Packaging $\&$ Pricing" document collection, also available through http:// roswell.tobaccodocuments.org. The terms "excise" and "tax" were also entered into the search engine, returning 113 and 141 results, respectively.

Based upon the documents returned by this method, we pursued documents written by or to Myron Johnston of Philip Morris and Diane Burrows of RJR at the Philip Morris and RJR's document websites as linked through http:// www.tobaccoresolution.com, in all "Name" fields (author, recipient, copied, named person). This strategy retrieved a large number of results, especially in the case of Myron Johnston. Entering "Pauthor: johnston, me" (searching author field alone) into the search engine at the Philip Morris document website (http://www.pmdocs.com) returned 20280 hits. The name is also entered in a number of ways. For example, entering "Pauthor: johnston,me" (eliminating the space between last name and first initials) returned 892 hits, highlighting the sensitivity of changes in punctuation, search string construction, etc, upon the retrieval process.

Keyword searches were also employed at Tobacco Documents Online (http://www.tobaccodocuments.org). This theoretically searches all data available through http:// www.tobaccoresolution.com at once, since TDO utilises a copy of the master " $4 \mathrm{~b}$ " index used to track all industry documents. ${ }^{7}$ Attempts to augment search results from the Youth and Marketing collection using terms such as "pric*" and "tax" across all company databases at also returned large numbers of documents (34377 and 15718 , respectively). Combining the two terms yielded a more manageable 698 documents. Similarly, searching on terms that would capture price related marketing strategies turned up thousands of documents. "Coupon", for example, produced 14205 hits, while "value brand" produced 8834, "discount" produced 4829, and "cents-off" produced 1787 hits.

More narrowly defined searches on more specific topics produced more manageable numbers as well. For example, a search for "elasticity" on the www.tobaccodocuments.org site produced 307 documents. However, a quick review of these showed them to be a mix of documents where elasticity referred to "a measurement of the amount of smoke a smoker can take out of a cigarette" ${ }^{\prime \prime}$ as well as the documents that were relevant to the aims of this paper referring to the responsiveness of cigarette demand to changes in price. When this search was limited to those documents including "price elasticity", 127 were identified.

Searching of the documents was conducted over the period from February 2001 through early September 2001. As is clear from this discussion, well over 100000 hits were made during the search process. A combination of more narrowly defined searches and the information contained in the abstracts or titles for these documents (when available) was used to narrow the documents that were more carefully reviewed down to a manageable number. The use of the Youth and Marketing database as an initial filter for the universe of available tobacco industry documents allowed this study to capitalise upon, and to avoid duplicating, previous efforts in the field.

\section{RESULTS}

\section{Price elasticity of cigarette demand}

Well over 100 published studies estimating the impact of price on cigarette smoking have been conducted by economists and other researchers. ${ }^{5910}$ These studies apply econometric and other statistical methods to a variety of aggregated and individual level data from numerous countries, states, and other areas. These studies clearly demonstrate that changes in cigarette prices, resulting from changes in cigarette taxes, manufacturers' prices, and/or other factors, lead to changes in cigarette smoking. This research confirms one of the basic laws of economics-that of the downward sloping demand curve. This law states that as the price of a product rises, the 
quantity consumed of that product falls, and that as the price of a product falls, the quantity consumed of that product rises.

Economists use estimates of the price elasticity of demand to quantify the impact of a change in price on consumption. Formally, the price elasticity of demand is defined as the percentage change in consumption resulting from a $1 \%$ increase in price. While a relatively wide range of estimates has been produced for the price elasticity of demand for cigarettes, most of the estimates from the USA and other high income countries tend to fall in the relatively narrow range from -0.25 to $-0.50 .^{59}{ }^{10}$ This implies that if cigarette prices rise by $10 \%$, overall cigarette smoking will fall by between 2.5 and $5 \%$.

The changes in smoking that result from the price changes are the result of changes in both the number of smokers and the amount of cigarettes consumed by smokers. The changes in the number of smokers result from changes in smoking cessation, initiation, and reinitiation. Econometric studies employing survey data on individuals produce separate estimates of the impact of price on the number of smokers (reflected in "smoking participation" elasticities) and on the cigarette consumption of smokers (reflected in "conditional demand" elasticities). Several recent studies imply that half or more of the effect of price on overall cigarette smoking results from reductions in the number of smokers. ${ }^{112}$ Moreover, a number of recent studies conclude that youth smoking is relatively more sensitive to price than adult smoking, with some estimates implying that teen smoking is up to three times more sensitive to price than adult smoking..$^{9} 10$

Finally, because of the addictive nature of cigarette smoking, the long run response to a permanent change in cigarette prices will be larger than the initial, short run response, as some smokers gradually adjust to the new prices and these gradual adjustments add to the initial impact of price on some smokers. ${ }^{13}$ Estimates from econometric models that account for the addictiveness of smoking imply that the long run impact of price on smoking is about double the short run impact. ${ }^{14}{ }^{15}$

\section{Industry estimates of overall price elasticity of demand} In addition to the voluminous academic literature on the impact of cigarette prices on smoking behaviour, the tobacco company documents reveal that much internal research was conducted on this issue. These documents clearly indicate that the companies were well aware of the importance of price as a determinant of the demand for cigarettes. For example, in its "Interim report to stockholders" for the first quarter of 1969 , LEM describes the impact of the state cigarette tax increases of the 1960s on cigarette sales. ${ }^{16}$ After noting that the weighted average state cigarette tax rose from about 5 cents per pack to more than 9 cents per pack during the previous six years, the report states: "There is strong evidence to indicate that the consumer demand for cigarettes is elastic, as it is for most other products, and that the state cigarette excise taxes do affect sales wherever they are imposed. According to the US Department of Agriculture, in 28 states where cigarette prices have increased $12 \%$ in the last two years, sales have declined by $6 \%$; whereas in 21 other states where the price has increased $1 \%$, sales have increased almost 1\%." After factoring in inflation, the numbers described here are remarkably consistent with the short run elasticity estimates produced from the econometric studies of cigarette demand.

Similarly, in his "Economic forecast: 1975-1980", Philip Morris analyst Myron Johnston reviewed a number of economic and other factors that affect cigarette demand, and discussed the implications of these factors. ${ }^{17}$ With respect to price, he stated: "Still another factor is the price elasticity of cigarettes, i.e., the change in cigarette sales that will result from a change in the retail price of cigarettes. My calculations, using a variety of methods, show the price elasticity of cigarettes to be -0.43 . This means that a $10 \%$ increase in the retail price of cigarettes will, other things being equal, lead to a $4.3 \%$ decline in unit sales." He noted, in a footnote, that the estimated price elasticity produced using a different method by the US Department of Agriculture's Robert $\mathrm{H}$ Miller is -0.42 , "remarkably close to my own figure".

Almost identical estimates were produced by Herbert Lyon of the University of Houston and M Lynn Spruill of the University of Kentucky in their report "A temporal crosssectional analysis of cigarette price elasticity in the United States", produced for the Tobacco Merchants Association in September $1977 .^{18}$ They summarised their research as follows: "In this study, price elasticities of cigarette demand for the United States and nine individual regions were estimated by covariance regression analysis. Six cross-section samples provided the data base for the analysis. Based on earlier experimental work, the estimates in this study can be considered the least biased yet developed. The value of the cigarette price elasticity of demand for the United States was estimated at -0.45 . This finding reinforces some of the earlier work in this area. Collectively these studies indicate that cigarette price elasticity of demand is about $-0.50 . "$

More than a decade later, the Policy Economics Group at KPMG Peat Marwick conducted a new analysis of the price elasticity of cigarette demand on behalf of Philip Morris. ${ }^{19}$ This study applied methods used in previously published studies of cigarette demand ${ }^{2021}$ to updated data on cigarette sales, explored how elasticity had changed over time, and provided estimates from models applying an economic model of addictive behaviour ${ }^{13}$ to cigarette demand. Based on their time series data, the authors estimated an overall elasticity of -0.60 for the period from 1947 through 1987. They noted that elasticity has changed dramatically over time: "The elasticity fell during the period from 1947 to 1957, then increased during the period from 1957 to 1987." They went on to state: "The reasons for the current increasing trend are unclear, but the statistics indicate that the increases in recent years have been significant." As with the econometric studies discussed above, the authors found that the long run price elasticity of demand after accounting for addiction is higher than that obtained when addiction is ignored.

Similar estimates are contained in a Management Sciences Associates 1991 report for Philip Morris. ${ }^{22}$ In this analysis, monthly data from January 1983 through June 1990 were used to estimate the impact of prices on total US sales volume, using two alternative measures of price-one based on manufacturer price plus taxes, and a second based on retail prices. These analyses produced estimated price elasticities of -0.51 and -0.52 for total industry volume.

Related to this are many documents that describe the impact of state tax increases on cigarette smoking within a given state. For example, two documents from Philip Morris described the impact of the 1989 increase in the California cigarette excise tax from 10 cents to 35 cents per pack ${ }^{23}$; ; one of these also includes a discussion of the impact of the New York tax increase of May 1989 which raised the state tax by 12 cents. ${ }^{23}$ These two state tax hikes received particular attention given the size of the markets affected by the increases. Significant declines were observed in response to both state tax increases. Based on data from a Nielsen panel, total industry cigarette sales in California declined by $7.6 \%$ for the period from January through August 1989, compared to the prior year. Similarly, New York sales declined 6.2\% from May 1989 through August 1989. As Peggy Martin summarised for the California tax hike: "Relative to smokers in other states, Californians reduced their cigarette consumption, increased their quit rates, and accelerated their switching to price values."

Similarly, a 1994 report prepared by SE Surveys, Inc for Lorillard described the findings from a study of three tracking surveys of Michigan smokers (from a statewide sample, a sample from the Grand Rapids marketing area, and a sample of black smokers) that looked at the impact of the 50 cent 
increase in the Michigan cigarette excise tax on 1 May $1994 .^{25}$ The study reported that two months after the tax increase, there was a significant reduction in the number of smokers in all three samples, with the number of smokers in the statewide sample falling by $7 \%$, in the Grand Rapids marketing area falling by $10 \%$, and among blacks falling by $4 \%$.

These experiences in California, New York, and Michigan, where higher prices resulting from increased cigarette taxes led to significant reductions in the number of smokers, confirmed the findings of a national survey done by The Roper Organization Inc, on behalf of the Tobacco Institute in $1978{ }^{26}$ Among the many questions asked in the survey was a series of questions asking smokers whether or not they would continue to smoke after tax increases of 5 cents, 50 cents, and \$1. In response, $93 \%$ of all smokers indicated that they would continue smoking after a 5 cent per pack tax increase, while $62 \%$ and $41 \%$ said the same after tax increases of 50 cents and $\$ 1$, respectively. Whether or not a smoker would give up smoking was correlated with how heavily they smoked, with the light and moderate smokers more likely to indicate that they would quit than those smoking a pack or more per day. In addition, smokers were asked if they would smoke more if cigarette taxes were eliminated. Relatively few (10\%) indicated that they would increase their cigarette consumption, while most $(80 \%)$ said they would continue to consume the same amount.

These are but a handful of the documents describing the impact of prices on overall cigarette smoking contained in the industry documents. They do, however, clearly illustrate that the industry conducted a variety of its own studies estimating the price elasticity of cigarette demand and that these studies clearly demonstrated that changes in cigarette prices would have a significant impact on cigarette demand.

\section{Price elasticity of youth and young adult smoking}

Economic theory suggests several factors that would make youth and young adult smoking more sensitive to price increases than adult smoking. ${ }^{5}{ }^{10}$ These include: the fact that young smokers who have been smoking for a shorter time are likely to be less addicted than older smokers and, as a result, will more quickly adjust to price changes; that youth have lower incomes, making them relatively more responsive to changes in the prices of the goods and services they consume; that peer effects are more important among youth, multiplying the effects of a price induced change in youth smoking; and that youth are more present oriented and, hence, more responsive to changes in the immediate costs of smoking.

Some of these same factors are identified in the tobacco company documents as reasons for why smoking among younger persons would be more sensitive to price. Myron Johnston, for example, stated in one internal Philip Morris memorandum from 1981 that: "Many of us have hypothesized that price elasticities are different for different demographic or socioeconomic groups, e.g., that price increases would have less effect on the higher income groups and on the older and therefore more habituated smokers, than on other smokers." ${ }^{27}$ This follows a 1975 memo of his describing "the decline in the rate of growth of Marlboro Red" in which he states: "I think price elasticity, like income elasticity, has a greater effect on lower income people than on those with higher incomes. As mentioned above, Marlboro smokers, being younger, tend to have lower incomes. Thus, Marlboro sales are probably more responsive to price changes than are the sales of brands which appeal to older segments of the population."28

In contrast to the relatively frequent industry studies of the price elasticity of demand of overall cigarette smoking, there are relatively few industry studies on the price elasticity of youth and young adult smoking. As Johnston described, in his comments on the earliest studies on price elasticity for different population subgroups, this is in part because the data needed to conduct this type of study are not readily available: "in fairness to other researchers (myself included) who have wrestled with this problem, it should be noted that the authors were privy to information not accessible to other investigators: The PHS public use tapes made available to the general public have been purged of all information that would compromise the confidentiality of the data (e.g. name and address). The authors of this paper, however, working as they did under a PHS grant, had the complete file and, on the basis of the addresses, were able to assign a price per pack figure for all respondents." ${ }^{29}$ Instead, many of the industry documents that were identified as dealing with the price elasticity of youth/young adult smoking discussed the findings from academic research on this issue.

No studies on this issue attracted more attention or generated more internal memos than the two studies by Lewit and his colleagues at the National Bureau of Economic Research (NBER). The first of these, published in 1981, focused on the impact of taxes, anti-smoking advertising, and other factors on teenage smoking, ${ }^{30}$ while the second considered the impact of taxes on smoking among adults in different age and sex subgroups. ${ }^{31}$ These were the first studies to use individual level data from national surveys to look at how smoking among different population subgroups responded to cigarette prices. The study on teens used data from cycle III of the Health Examination Survey from the late 1960s, and estimated that the price elasticity of teenage smoking participation was -1.20 , while the overall price elasticity of teen smoking was $-1.44{ }^{30}$ This was more than three times the estimated elasticity of -0.42 obtained from the study of adults, based on data from the 1976 National Health Interview Survey. ${ }^{31}$ In addition, the study for adults concluded that younger adults were much more sensitive to price than older adults, with the price elasticity for persons ages $20-25$ estimated at -0.89 , and that men, particularly young adult men, were very responsive to price, while women were relatively insensitive to price. Finally, both studies concluded that most of the impact of price on youth and young adult smoking was on the decision to smoke, in contrast to average daily cigarette consumption which was less affected by price.

These studies generated a flurry of memos from Myron Johnston at Philip Morris, in part because of the credibility of the studies and in part because of the support they would provide for advocates of higher cigarette taxes. With respect to the second study (on adult smoking), Johnston stated: "This paper is undoubtedly the best work I have seen to date on price and income elasticities of cigarettes." ${ }^{29}$ Similarly, with respect to the first study (on youth smoking), Johnston stated: "Because of the quality of the work, the prestige (and objectivity) of the NBER, and the fact that the excise tax on cigarettes has not changed in nearly 30 years, I think we need to take seriously their statement that ... if future reductions in youth smoking are desired, an increase in the Federal excise tax is a potent policy to accomplish this goal. Given that a further reduction in youth smoking IS the goal of many pressure groups and Federal agencies, and that the goal of balancing the Federal budget through budget cuts seems increasing elusive, I think we can expect an increase in the excise tax on cigarettes, probably within a year." ${ }^{27} \mathrm{He}$ went on in this memo to note: "There are other things that lead me to believe that there will be increases in the Federal excise taxes on both cigarettes and alcoholic beverages: (1) It can be argued that excise taxes are "voluntary" taxes in that payment of them can be avoided by refraining from purchasing the product, and that therefore increasing excise taxes does not reduce discretionary incomes, (2) Both cigarettes and alcoholic beverages have low price elasticities, so the additional taxes can be passed on to the consumer with little adverse effect on the industries, (3) Prices of cigarettes and alcoholic beverages (as measured by the Consumer Price Index) have increased more slowly than prices generally, (4) Excise taxes contributed only 
$5.0 \%$ to total Federal revenues in 1980, down from $8.1 \%$ in 1970 and $12.5 \%$ in 1960, (5) A 25\% increase in the excise taxes on cigarettes and alcoholic beverages would reduce the Federal deficit by over two billion dollars, yet have a minimal effects on the Consumer Price Index. Given the current price of gasoline and the state of the automobile industry, I do not think it would be politically feasible to raise excise taxes on cars or gasoline, but I think cigarettes and alcoholic beverages are fair game for increased taxes." As it turned out, Johnston's forecasts were at least partly accurate, with the federal cigarette excise tax doubled in late 1982 (effective I January 1983 ) as part of that year's Tax Equity and Fiscal Responsibility Act, and the distilled spirits tax increased in 1984 (effective 1985) as part of a deficit reduction package.

In his memos on Lewit and colleague's ${ }^{30}$ study of youth price elasticity, Johnston provided a very interesting discussion of how he saw the price of cigarettes interacting with a variety of other factors-notably incomes and the prices of other goods and services-in affecting teen cigarette smoking. With respect to the role of income, he stated: "The authors concede that one reason for the large price elasticities they found among teenagers is that the elasticities incorporate income effects and substitution effects, i.e., cross-elasticities." He went on to note: "Among teenagers the prevalence of cigarette smoking is highly correlated with income (from either allowances or working) while there is no similar correlation between smoking prevalence and income among adults." With respect to the prices of other goods and services, he stated: "With regard to the substitution effects, or cross-elasticities, I think the most important substitution effect is with gasoline." After describing how the relative prices of gasoline and cigarettes have changed over time, he went on to state: "I think it is more than coincidental that the sharpest declines in smoking prevalence among teenage males occurred in 1979 and 1980, the years when the price of gasoline rose most sharply. When it comes to a choice between smoking cigarettes or cruising around in his car, the average teenage male would probably choose the latter." These ideas are wrapped up in the notion of affordability, which relates the price of cigarettes to the prices of other goods and services and to income.

Several years later, Johnston reviewed the evidence on the trends in teenage smoking during the 1980s to determine whether or not the cigarette price changes of the early 1980s led to significant reductions in youth and young adult smoking. ${ }^{32}{ }^{33}$ In a 1992 memo, he noted that the trends in teenage smoking observed in the 1980s and some information on the early response to the California cigarette tax increase in 1989 are inconsistent with the hypothesis that the price increases in 1982-84 adversely affected smoking initiation. ${ }^{33}$ However, in an earlier 1988 memo, he delved more deeply into why the declines in youth smoking may have been overestimated for the 1980s. ${ }^{32}$ Returning to his hypothesis about the importance of cross price effects, he stated: "As it happens, the end of the decline in smoking prevalence did coincide with the stabilization of gasoline prices, and the fact that smoking prevalence has been inching up since 1981 among whites lends some credence to the gasoline hypothesis. The gasoline hypothesis could also explain the increase in the proportion who begin to smoke after high school graduation: After high school graduation, many young people go to work full time and thus have the money to buy both the gasoline and the cigarettes." He followed this with a related notion: "The percent who reported that they rode around in a car nearly every day declined with the decline in cigarette smoking from 1978 to 1981, as a result, no doubt, of the gasoline price increases. This could have been causally related to the decline in smoking, since teenagers for decades have been using their cars to engage in activities disapproved by their parents. Another thing that declined as smoking declined was getting together with friends informally. This may have been related to the gasoline shortage and price increases, and probably resulted in less contact with others who smoked and in fewer occasions for smoking."* Likewise, in one of his earliest memos on the NBER studies, Johnston noted that several related factors would likely moderate the effect of the expected federal excise tax increase, including "The almost certainly improved economic conditions, lower inflation rates, and increasing discretionary incomes". ${ }^{27}$

The two NBER studies generated a similar flurry of memos at RJR, where analysts were somewhat more sceptical about the precision of the estimates based on cross-sectional data, but accepted the findings concerning relative price sensitivity. As marketing researcher Diane Burrows stated: "The NBER elasticities may not reflect the exact effects of price increases, since their models didn't deal with changes over time. However, the effects they found for other variables (race, income, working women, etc) are highly consistent with our understanding of market dynamics. Thus, it is likely that the NBER models have correctly identified relative price sensitivity among age/sex groups." ${ }^{\prime 35}$

In these memos, Burrows went on to discuss the short and long term implications of the differences in price sensitivity by age and sex that are estimated in the two studies. She concluded: "In terms of the immediate impact, the effect of price on males $35+$ is the most important. Half $(50 \%)$ of the total drop in industry volume is attributable to males $35+$ compared to $24 \%$ from younger adult males and $7 \%$ from teenagers. (Calculated in Attachment A). But, the loss of younger adult males and teenagers is more important to the long term, drying up the supply of new smokers to replace the old.* This is not a fixed loss to the industry: its importance increases with time. In ten years, increased rate per day would have been expected to raise this group's consumption by more than $50 \% .^{.35}$ In related memos and reports, Burrows and her colleagues outlined the marketing implications of the findings from the NBER studies that youth and young adults, particularly males, are relatively sensitive to price. ${ }^{36-39}$ These memos and reports similarly noted the importance of imagery to younger smokers and are consistent with the fact that while relatively price sensitive, youth smoke the most heavily advertised premium brands. These implications are discussed further below.

In addition, the findings from the two NBER studies were consistent with the evidence contained in internal RJR marketing studies, including their 1983 Segment Description Study, and Project VB ASSESSOR Analysis. ${ }^{38}$ The 1983 Segment Description Study, for example, assessed the short term impact of the federal cigarette excise tax increase in 1983 on smoking rates using data from the marketing development department's panel of tobacco users ages 18 and older. This study concluded that the doubling of the federal tax led to an initial decline of $7.1 \%$ in the number of smokers due to quitting, with a much larger drop-14.4\%—among 18 through 24 year old smokers. ${ }^{40}$

Similarly, a 1988 RJR presentation on younger adult smokers provided an overview of relevant trends for this group (defined as 18-24 years), discussed factors affecting their smoking, and provided recommendations on how to increase sales of RJR products to this group. ${ }^{41}$ With respect to smoking prevalence in this group, RJR analysts stated: "The disproportionately high rate of incidence decline among YAS [young

*Interestingly, in a memo from around the same time, Johnston discusses the effects of higher food prices on overall cigarette demand. ${ }^{34}$ In this memo, he notes that it is possible that the significant increases in food prices (particularly meat prices) that were occurring in the late 1980s, could have "a small effect on per capita cigarette consumption", but that because of a rapid rise in inflation adjusted per capita disposable income, the effects were more likely to be negligible. 
adult smokers] is tied to heightened price sensitivity and social acceptability. Increasing prices, however, appear to be the most important factor as YAS appear to be more concerned about the price or value of cigarettes than the market in general." This conclusion is based on data from their 1988 SIRS that indicated that on a series of behaviours reflecting a "savings mindset", including several related to cigarettes, young adult smokers consistently responded in a way that reflected greater concern about price/value.

Marketing data on adult price sensitivity from Lorillard similarly show that young adult smokers were the most sensitive to price. ${ }^{42}$ For example, their 1991 tracking survey included two price related questions, one based on which characteristic of cigarettes would be most important if the smoker were to switch to another brand (taste, low tar and nicotine, or price) and a second based on whether or not the smoker bought a brand other than their usual because it had a lower price or greater value among the brands available. When broken down by age groups: "it is clear that the younger adult, 18-24 smoker group, although still smoking a full price brand, "claim" a greater sensitivity to price than the older age groups. Furthermore, among those who claim to shop for price, it is the younger age group that exhibits the highest switching rate." As discussed more fully below, it is often price related promotions that contribute to brand switching among younger smokers.

As these and other documents clearly demonstrate, tobacco companies were concerned about the impact of price on smokers in different age groups, particularly the younger groups on whom their future success depended. Their own internal marketing studies and their reviews of academic studies on this issue clearly indicate the industry's recognition that price is a particularly important determinant of smoking behaviour among the young.

\section{Implications for pricing strategies \\ Pricing strategies}

As described above, for much of its history, cigarette industry pricing strategies have been characterised by price leadership where, typically, the dominant firm of the time will initiate a price increase or decrease and the others in the industry will follow almost immediately with identical changes in their prices. An interesting 1976 report from the business planning and analysis division of Philip Morris on "Pricing policy" clearly illustrates that the firms in this industry understand this and that it has some impact on their own pricing strategies ${ }^{43}$ By way of providing some background, the report began with this description of the industry's pricing behaviour: "The cigarette industry is characterized by economists as a "kinky oligopoly". This charming term implies that the general price level is determined by a small number of firms (price leaders); that no economic advantage can be obtained by any one firm pricing below the general price level; and that major disadvantages accrue to a firm which attempts a price above the general level. In short, the general price level results from some sparring among the potential price leaders, after which the rest of the industry accepts the resulting price structure."

The report went on to note that Philip Morris had historically been one of the followers in the industry, with its own prices based on the prices established by American Tobacco or RJR. Most of the price increases during this period were relatively modest and it was a period of relatively low inflation. However, the report noted that by the mid 1970s, things had changed. Specifically, higher rates of inflation had emerged which, if not kept up with, could have a damaging effect on profits. In addition, "The second change which has occurred is the emergence of Philip Morris among the price leaders in the cigarette industry. We no longer follow the market; whether we initiate a price increase or not, our decision is a key factor in establishing a new industry price level, and we must examine any price move in the light of our own judgment of the appropriate level."

The report provides a fascinating look at how Philip Morris and, as a result of its leadership position, the rest of the industry, priced its products in the late 1970s. For example, the report clearly described the tradeoffs between pricing and other marketing efforts, noting that the relative lack of price competition in the industry provides earnings that can be invested in other marketing efforts in order to gain or maintain market share. Similarly, it recognised the uneasy relationship among the firms in the industry by noting that while prices are well below the level that would maximise profits for the industry, attempting to sharply increase prices would be unlikely to produce equilibrium at a higher price, but would instead "destroy the resiliency of the system". This may have, in part, reflected the awareness of greater price sensitivity among the potential young smokers needed to sustain the industry in the long run. That is, if prices were set higher in order to maximise short run profits, the resulting reductions in youth smoking would lead to a significantly smaller number of smokers in the long run, lowering future profits. Several different strategies are discussed in this report, including: a straight pass through of the higher costs resulting from inflation; a pricing policy that would maintain the relatively high profit margins that had been earned historically; one which would provide earnings growth; and one that would sustain the rate of return on assets. In the end, the report indicated that a "full inflation price relief" strategy is selected that will allow for both the increased operating and capital costs to be passed on to smokers while remaining defensible.

The price increases of the late 1970s and early 1980s essentially reflected this strategy. Premium brand manufacturers' list cigarettes prices were $\$ 12.75$ per thousand cigarettes for all major manufacturers by December of 1975 , and rose to $\$ 20.20$ per thousand by September 1981. ${ }^{44}$ While nominal prices were rising sharply, so too was inflation; after adjusting for inflation, the real price of cigarettes actually fell somewhat (by almost 6\%) during this period.

At the end of this period, as described by Philip Morris' Myron Johnston, ${ }^{27}$ it was becoming more and more likely that there would be a federal cigarette excise tax increase in 1982 or 1983. Eventually, the federal tax was doubled, effective 1 January 1983. At this point, it appears that the industry diverged from this pricing strategy. Instead of continuing to raise prices to more or less keep pace with inflation and to cover the expected federal cigarette tax increase, prices were raised more rapidly. As Johnston described several years later, when discussing strategies for handling an anticipated increase in the federal tax in the late $1980 \mathrm{~s}^{45}$ : "Last time, of course, we increased prices five times between February of 1982 and January of 1983. In less than a year, the price went from $\$ 20.20$ to $\$ 26.90$ per thousand ( $\$ 2.70$ more than the tax), and this fact was not lost on consumers, who could legitimately blame the manufacturers for the price increases. While price increases of this magnitude might have been tolerated during the rapid escalation in the overall inflation rate between 1977 and 1981, the increase in the price of cigarettes in 1982-83 was made even more dramatic by the fact that the overall rate of inflation was slowing considerably."

At least one academic study speculated that the industry used the 1983 federal cigarette tax increase as a coordinating mechanism to further raise prices and profitability. ${ }^{46}$ In his comments on this study, Johnston seemed to confirm this speculation ${ }^{47}$ : "The conclusion of greatest interest to us, and one with which I cannot disagree, is that by increasing prices by more than the amount of the excise tax, we priced ourselves out of the market." Given the studies by Lewit and his colleagues discussed above, ${ }^{30}{ }^{31}$ Johnston went on to note that Philip Morris was likely to be disproportionately affected by the 1983 tax increase and related industry price increases 
given that its market shares are larger among younger smokers, stating that "We don't need this to happen again" in his memo on how to handle the tax increase that was anticipated at the time.

Instead, Johnston argued strongly against repeating the behaviour preceding the 1983 tax hike. He stated: "I have been asked for my views as to how we should pass on the price increase in the event of an increase in the excise tax. My choice is to do what I suggested to Wally McDowell in 1982: Pass on the increase in one fell swoop and make it clear to smokers that the government is solely responsible for the price increase, advertise to that effect, suggest that people stock up to avoid the price increase, and recommend that they refrigerate their cigarettes "to preserve their freshness." . . .Then when people exhaust their supply and go to the store to buy more, they will be less likely to remember what they last paid and will be less likely to suffer from 'sticker shock'. As a result, they should be less likely to use the price increase as an incentive to stop smoking or reduce their consumption." ${ }^{45}$

While the anticipated tax increase of the late 1980s never happened, federal cigarette taxes were next increased by 4 cents per pack on 1 January 1991. The response Johnston suggested was adopted by at least some firms in the industry. RJR, for example, issued a statement just before the tax hike stating: "R.J. Reynolds Tobacco Co.'s price increases reflect the increased costs it incurs doing business: labor costs, raw materials costs (including, but not limited to, leaf), fuel costs, packaging and equipment costs, etc." ${ }^{48}$ The memo went on to raise themes that would continue to be employed in future industry efforts opposing higher taxes: "We do oppose increases in federal, state and local excise taxes, and we encourage other members of the industry family to do so. Such taxes are regressive-those on a fixed income pay the very same amount as millionaires. Further, the industry already is carrying its fair share of the tax burdencontributing $\$ 10$ billion in excise and sales taxes annually."

\section{Discount brands}

A few of the factors discussed above came together in the early 1980s to change significantly the nature of price competition in the cigarette markets. Rising inflation and increasing cigarette taxes and prices that outpaced inflation combined with the economic downturn of the early 1980s to reduce significantly the affordability of cigarettes. Per capita cigarette sales declined by nearly $8 \%$ from 1981 to 1985 after remaining mostly flat since the mid1970s. As some of the documents discussed above described, the industry saw smoking as becoming increasingly sensitive to changes in cigarette prices. In addition to seeing reductions in smoking, smokers began to switch to the heavily discounted generic brands, with market share for generics tripling after the 1983 tax increase. ${ }^{37}$ Some companies, notably RJR, felt particularly at risk given the age/ sex/income composition of their customers.

A 1983 report from RJR highlighted these concerns and suggested a response, stating: "The outlook for the future suggests that the price-sensitive environment will continue and perhaps worsen. State taxes are likely to increase. Another F.E.T.[federal excise tax] increase is possible. Contrary to our previous efforts and experience, discounted, branded cigarettes may well be successfully introduced and a multi-tiered retail price structure normally associated with such "price wars" may result. There would be heavy competitive activity and differing margins associated with the multi-tier structure." ${ }^{37}$ Similar concerns were being expressed throughout the industry and similar responses were being considered.

As the largest firm in the industry in 1980, but one that was seeing its market share eroded by Philip Morris' ability to attract younger smokers, RJR was particularly concerned about these trends. This is clearly seen in the company's internal documents from the 1980s in which a variety of options, including many related to price, are considered and tested. As a 1984 Strategic Research Report described: "Pricing is a key issue in the industry. Some evidence suggests that younger adult smokers are interested in price, but unlikely to adopt a brand whose only "hook" is price. To maximize the possible pricing opportunity among younger adult smokers, several alternatives should be considered." ${ }^{37}$ The report went on to describe what would eventually become the "branded generics" that came to dominate the discount cigarette markets in the 1980s and afterwards: "A price/value brand would need a conspicuous second "hook" to reduce possible conflict between younger adults' value wants and imagery wants. The most saleable "hooks" are likely to be based on product quality, since these provide easy-to-explain public reasons for switching. Suitable imagery should also be used."

RJR's "Project VB Assessor" was one of its early efforts in entering the discount markets. ${ }^{49-51}$ This was the internal name for the work that went into the development and eventually marketing in 1983 of the firm's Century brand. The price based "hook" in the case of Century was twofold. First, they were sold at a lower price per pack than premium cigarettes, and second, each pack contained 25 rather than 20 cigarettes (cartons included nine packs rather than 10, for an extra 25 cigarettes per carton). In addition, the brand was advertised as a quality product that provided greater value: "Taste that delivers in a pack that saves.." ${ }^{\prime 1}$ The early success of Century-it gained $1 \%$ of the market less than one year after being introduced-led RJR to move more aggressively into the discount cigarette markets, repositioning its Doral brand as a discount brand soon after, and introducing its Sterling and Magna brands later in the 1980s.

Other companies saw a similar opportunity and also moved to develop brands for the discount markets. B\&W and Philip Morris followed RJR's lead in introducing "value 25s" with their Richland and Players brands, respectively, while all either developed new brands or repositioned old brands in the discount markets. Within a few years, a three tier price structure emerged, comprised of a relatively small number of deep discount brands (for example L\&M's generics, B\&W's GPC, and others), many branded discounts (including a number of former premium brands), and numerous premium brands.

By early 1993, the discount brands had captured nearly $40 \%$ of the total cigarette market and the availability of these low priced alternatives had contributed to slowing the declines in smoking observed through the 1980s and early 1990s. ${ }^{1}$ By early 1993, the price differences were significant. Regular size deep discount cigarettes were listed for as low as $\$ 32.70$ per thousand in January 1993, while comparable branded discounts were listed as low as $\$ 48.98$ per thousand. By comparison, regular sized premium brands were selling for $\$ 71.10$ per thousand. ${ }^{44}$

\section{Marlboro Friday}

While Philip Morris used its " 10 cent" brands of the early 1930 s to establish itself as a major player in US cigarette markets, it was having less success in the price wars of the late 1980 s and early 1990s. While clearly the dominant firm in 1991 (its market share was $43.4 \%$, compared to second place RJR's share of $27.8 \%$ ), Philip Morris was beginning to see its position erode as the discount brands captured more of the market. This was particularly true for its Marlboro brand. As one of the company's documents states: "if trends had continued and we hadn't taken action, Marlboro's share would have fallen to $18 \%$ by year end (from over $22 \%$ in early 1993), and the discount category would have grown to roughly $46 \%$ of the market."

In a bold move, on 2 April 1993, Philip Morris “announced a major shift in business strategy designed to increase market share and grow long term profitability in a highly price sensitive market". ${ }^{52}$ Through a series of promotional efforts, the 
immediate impact was a 40 cent per pack reduction in Marlboro prices. Because of its price leadership position described above and the dominance of Marlboro, others could do little more than follow or risk significant loss of their market share. Consequently, prices for all premium brands were sharply reduced almost immediately. One consequence of these price reductions was a sharp rise in youth smoking prevalence. ${ }^{5354}$ For Philip Morris, however, this strategy was highly effective. By the end of 1994, its market share had grown to $46.9 \%$, Marlboro's market share had risen to $30.0 \%$, and the upward trend in the market share of discount brands had been reversed. ${ }^{55}$

Implications for other price based marketing strategies In addition to the clear implications for its pricing strategies, the documents similarly demonstrate that the evidence on the impact of prices and taxes on cigarette smoking had implications for other tobacco company marketing strategies.

\section{Response to tax increases}

As the series of Philip Morris memos from Myron Johnston described above illustrate, industry responses to federal and state cigarette tax increases evolved over time as they gained experience from the impact of past tax changes. After the unsuccessful experiences resulting from more than passing on the 1983 federal cigarette tax increase to smokers, companies began to develop strategies to offset the impact of tax increases on consumers and/or to enlist smokers in their efforts to oppose proposed tax hikes.

Philip Morris, for example, developed a "defense plan" in response to California's Proposition 99 that raised the state's cigarette tax by 25 cents per pack in $1989 .{ }^{56}$ This plan considered a variety of activities designed to offset the short run impact of the tax increase, including couponing and multipack discounts, and included efforts via direct mail, at the point-of-purchase, and through the mass media. Different strategies were discussed for using different approaches to reach smokers with different characteristics (those who are brand loyal, those who are undecided, and those who are price sensitive). In addition to targeting California, the plan was to "test defensive elements for national rollout against future federal excise tax increase". A similar plan, based on the California experience, was developed in response to New Jersey's 1990 tax increase. ${ }^{57}$ At least one recent study provides empirical evidence that the strategies Philip Morris suggested have been used in states that have adopted significant cigarette excise tax increases and funded comprehensive tobacco control programmes with a portion of the revenues generated by the higher taxes. ${ }^{59}$

Similar strategies are discussed in an RJR memo planning for an expected 1987 federal cigarette excise tax increase. ${ }^{60}$ In addition, the plan called for including postage paid reply cards in cartons that would allow smokers to let their Congressperson know of their opposition to the tax hike, as well as the creation of a 1-800 number "for smokers to call for additional tax protection if an increase does in fact occur". Smokers participating in the call-in programme would have received six $\$ 1.00$ carton coupons by mail if the tax increase had taken place, a strategy described as "self-selecting, or targeted to price-sensitive franchise smokers".

Other documents show how some of these strategies were implemented. For example, Philip Morris documents from 1991 and 1992 contained ads for its discount Cambridge brand that showed newspaper clips referring to recent Pennsylvania, Maryland and/or Washington state cigarette tax increases. ${ }^{62}{ }^{6}$ The ads included a coupon for $\$ 1$ off the purchase of two packs as a way to "get tax relief". RJR did much the same in a 1991 Salem ad that contained a newspaper clip with the headline "Delaware joins FEDS in increasing cigarette taxes". ${ }^{63}$ This ad included a \$1 off coupon for the purchase of either four packs or one carton of Salem cigarettes (fig 1).
The strategy of providing price reductions through coupons, multi-pack discounts, and other promotions that are described in these documents appear to have been relatively widely employed in response to the 1991 and 1993 federal cigarette excise tax increases and in response to the more recent settlement induced price increases. In the three years before the 1991 tax increase, cigarette companies reported expenditures of about $\$ 1$ billion per year on coupons and retail value added promotions to the Federal Trade Commission. ${ }^{64}$ During the three year period from 1991 through 1993, however, expenditures in these categories rose to almost $\$ 2.4$ billion on average, before declining to about $\$ 1.3$ billion per year from 1994 through 1996.

Similarly, following the Master Settlement Agreement, however, expenditures on coupons and retail value added programmes again rose significantly, going from just over $\$ 1.5$ billion in 1997 to almost $\$ 3.1$ billion in 1999. This massive increase in price related promotions cushioned the impact of the settlement related increases in cigarette prices during this time, leading to smaller reductions in cigarette consumption than would have otherwise resulted from the price increases alone. Consequently, the impact of the settlement on future death and disease resulting from tobacco use has been reduced by the tobacco companies' price related marketing strategies.

\section{Other price related marketing strategies}

Besides the activities described above, the tobacco company documents reveal a range of price related marketing strategies. In addition to the introduction of Century with its dual hook of more cigarettes at a lower price, RJR considered a number of other ideas in response to its perception that price sensitivity of cigarette demand was on the rise and had important implications for its long run success. Noting the greater price sensitivity of young adult smokers, for example, the 1984 Strategic Research Report discussed above stated: "Tactically, extended periods of closely targeted pack promotion (BIGIF (buy-one get-one free), sampling) in selected sites (e.g., convenience stores, military exchanges, special
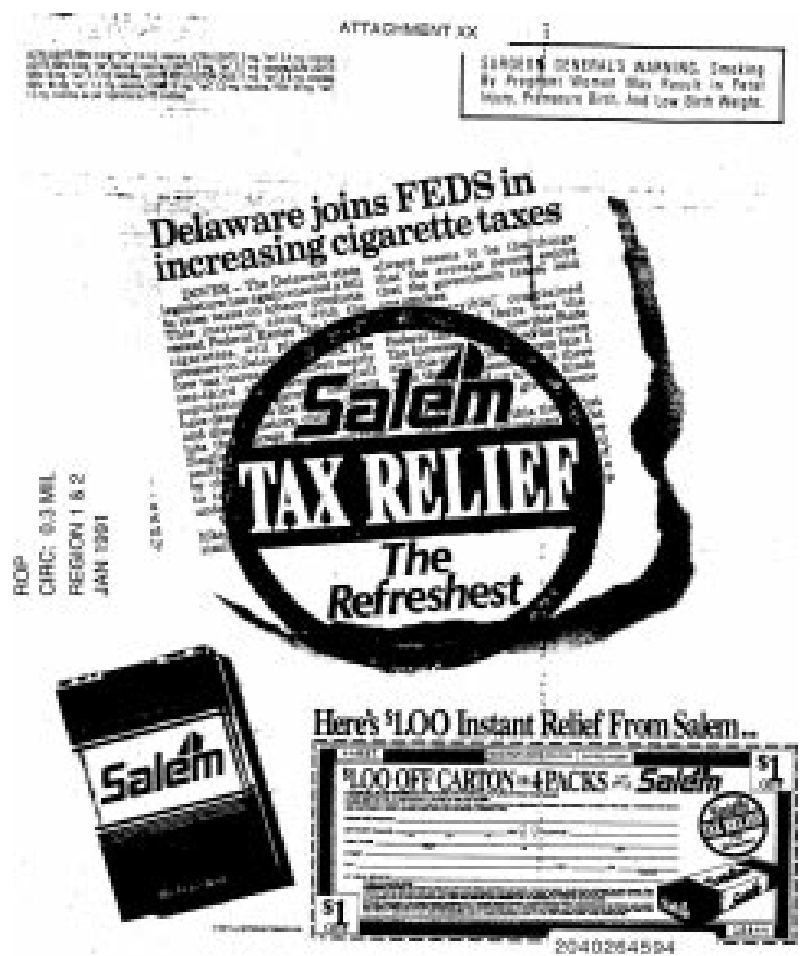

Figure 1 Salem "Tax Relief" advertisement and coupon. 
events) could lead to brand loyalty from repeated trial. This should be considered an investment program." ${ }^{39}$

These price related promotional efforts appear to have been a critical factor in the growth of RJR's Camel brand, particularly among younger smokers, in the 1980s and early 1990s. The importance of these efforts was noted early in the rise of Camel among young adult males in the Midwest, where it was observed that: "The major factor contributing to CAMEL's dramatic growth among Mid-West 18-24 year old males appears to be the increased level of Mid-West promotional support, and in particular, CAMEL's targeted promotions (which were implemented the same time as the boost in CAMEL's share and completed just prior to the downward trend )." ${ }^{65}$ These promotions included buy-three-get-three-free ("six pack") discounts, coupons, the "Camel Cash" programme, and other retail value added strategies. As described in a subsequent report, it appears that these promotions were critical to sustaining any increase in Camel's market share. ${ }^{66}$ Based on data from an RJR tracking survey, an almost $2 \%$ decline in Camel's market share among young adult smokers was observed during a more than one year period when promotional support for Camel was significantly reduced (from an expected $8 \%$ in the middle of the period to just over $6 \%)$. As the report stated: "While "Old Joe" might be able to generate growth by imagery alone, the above patterns suggest that retail pack programs play an important role in maintaining loyalty among the brand's YAS franchise during this key stage in brand choice, as well as in generating trial, which could stimulate further growth momentum. Thus, reducing CAMEL's pack presence would likely jeopardize the brand's ability to sustain the rate of YAS growth achieved in 1988." This suggests that the combination of imagery (Joe Camel) and price reductions contributed significantly to the growth in Camel's market share among teens and young adults in the late 1980s and early 1990s.

Similarly, even after Marlboro Friday, Philip Morris was still actively considering a number of other price related strategies to further expand its position as market leader. In an interesting document from a new product development meeting in June 1993, a number of projects are described that include some price "hook" ${ }^{67}$ Some of these were in the early stages, while others had been market tested and were ready to go. Project RX, for example, was "designed to capitalize on consumer price sensitivity by delivering a product that combines a rational price break with the equity and value of the Marlboro trademark". This product was ready to go and was waiting in the wings in the event of a federal excise tax increase. Project STEED, at an earlier stage of development, was described as: "the "no-frills" Marlboro that offers a more affordable means of purchasing Marlboro cigarettes. The "value pack" sold in 100, 200 and/or 300 stick units, contains individually wrapped "bundles" of 20 cigarettes, designed to be with a reusable Marlboro pack/tin. The perceived cost savings of eliminating the packaging on these "bundles" allows the "value pack" to be offered at a reduced price point without diluting brand equity."

Several issues were raised about the feasibility of project STEED, including the issue of how tax stamps would be dealt with. Project LIGHTHOUSE, on the other hand, aimed to create a deep discount brand-Player's Navy Cut - that would be Philip Morris' "Camel fighter, positioned as the discovery brand for YAMS" in a way that would not appeal to young male Marlboro smokers. Project Royce took this one step farther, further emphasising the role of price: "Royce is the low cost easy-to-'Roll Your Own' cigarette made with quality tobaccos and filter tubes/papers. In markets where premium brands retail for $\$ 2.20$ per pack, Royce would retail for approximately $\$ 1.00$ on an equivalent 20 stick basis." Project Phoenix went in a somewhat different direction. This cigarette is described as: "an FET (federal excise tax) contingency. A slow burning cigarette that is equivalent to two standard ciga-

\section{What this paper adds}

Numerous econometric studies have clearly demonstrated the impact of price on cigarette smoking. These studies conclude that higher cigarette prices resulting from increased cigarette taxes and/or industry initiated price increases induce cessation, prevent relapse among former smokers, reduce initiation, and lower the number of cigarettes consumed by continuing smokers. In addition, this research demonstrates that changes in cigarette prices have their greatest impact on younger, lower income, and/or less educated persons.

This paper describes results from an analysis of internal tobacco industry documents that discuss the impact of prices and taxes on cigarette smoking, industry responses to anticipated or actual state and federal excise tax increases, and the companies' use of price related marketing strategies. This analysis provides clear evidence on the industry's knowledge concerning the impact of cigarette prices on cigarette smoking, describing how tax related and other price increases lead to significant reductions in smoking, particularly among young persons. As further shown in the documents, this knowledge was important in developing the industry's pricing strategies, including the marketing of lower price branded generics and the pass through of cigarette excise tax increases, as well as in developing a variety of price related marketing efforts, including multi-pack discounts, couponing, and others. This analysis suggests that tobacco control efforts that aim to raise prices and limit price related marketing efforts will be important in achieving reductions in tobacco use and the public health toll caused by tobacco.

rettes, with Phoenix, only half the normal taxes are payable on a per smoke basis-and consumers get the benefit of flexibility and control of when and how much to smoke." In addition, other concepts were under consideration, including additional changes in the number of cigarettes per pack (10s, 14s, 25s, and 30s) and on pack couponing.

\section{CONCLUSIONS}

The tobacco industry documents contain a wealth of information concerning the companies' price related marketing strategies. These documents clearly support the findings from academic and other research that demonstrate that price is a key determinant of overall cigarette smoking, that price increases lead to significant reductions in overall smoking, increases in smoking cessation, and reductions in smoking prevalence, with relatively large effects on young people. Moreover, the documents clearly indicate how tobacco companies used price based marketing efforts to respond to tax changes and other tobacco control efforts.

The tobacco industry's own internal documents confirm the effectiveness of large cigarette excise tax increases as a potent policy for governments in their efforts to reduce tobacco use, particularly among the young. In addition, they suggest a number of other potential policy options aimed at reducing the industry's ability to engage in price based marketing. Recent analyses conclude that comprehensive approaches are needed to reduce tobacco company marketing to the point where significant reductions in tobacco use would be achieved ${ }^{669}$ If partial limits are placed on advertising and promotion, resources that were once spent on the now limited activities can be easily diverted into other marketing efforts.

The documents clearly indicate that price related marketing efforts, including couponing, multi-pack promotions, cents-off discounts, and others became more prevalent in the 1980s and 1990s, in response to competitive pressures, as well as a means of cushioning the impact of price increases resulting from tax increases and the pass through of settlement 
costs. Recent data and research suggests that these have become even more important in the USA in the wake of the Master Settlement Agreement that eliminated billboard advertising and a variety of other advertising and promotional activities. ${ }^{64} 70$ Given the importance of price as a determinant of youth smoking, this suggests that widening restrictions on advertising and promotion to include price related promotions would be important in further limiting the ability of tobacco companies to attract new smokers and, in the long run, significantly reducing the public health toll from tobacco. Similarly, it suggests that large increases in cigarette taxes, such as the $\$ 2.00$ per pack tax increase proposed by some groups during the recent debate over national tobacco legislation in the USA, would be particularly effective given that the resulting price increases would be much more difficult for tobacco companies to offset through price related promotional efforts.

\section{ACKNOWLEDGEMENT}

The research described in this paper was supported by grants from the National Cancer Institute CA77021-03, CA87696-01, and by Core Grant CAl6056-26.

\section{Authors' affiliations}

F J Chaloupka, Department of Economics, University of Illinois at Chicago, Chicago, Illinois, USA

K M Cummings, C Morley, J K Horan, Department of Cancer Prevention, Epidemiology \& Biostatistics, Roswell Park Cancer Institute, Buffalo, New York, USA

\section{REFERENCES}

1 Kluger R. Ashes to ashes. New York: Alfred A Knopf, 1996.

2 Jaffe AB. "Cigarettes". In: Adams W, Brock J, eds. The structure of American industry, 10th ed. Upper Saddle River, New Jersey: Prentice-Hall, Inc, 2001

3 Tenant RB. The American cigarette industry: a study in economic analysis and public policy. New Haven, Connecticut: Yale University Press, 1950

4 Scherer FM, Ross D. Industrial market structure and economic performance, 3rd ed. Boston: Houghton Mifflin Company, 1990.

5 US Department of Health and Human Services. Reducing tobacco use: a report of the Surgeon General. Atlanta, Georgia: US Department of Health and Human Services, Centers for Disease Control and Prevention, National Center for Chronic Disease Prevention and Health Promotion, Office on Smoking and Health, 2000.

6 Cummings KM, Morley CP, Horan JK, et al. Marketing to America's Youth: evidence from corporate documents." Tobacco Control 2002;11 (suppl I):i5-17

7 Malone RE, Balbach ED. Tobacco industry documents: treasure trove or quagmire? Tobacco Control 2000;9:334-8.

8 Gonterman R. Elasticity Data/399. Brown \& Williamson Tobacco Corporation. April 7, 1992. Access date: December 3, 2001. Bates No. 570252204-570252206. http://www.bwdocs.aalatg.com/

9 Chaloupka FJ, Warner KE. The economics of smoking. In: Culyer AJ, Newhouse JP, eds. Handbook of health economics. Amsterdam: North Holland, 2000.

10 Chaloupka FJ, Hu TW, Warner KE, et al. The taxation of tobacco products. In Jha P, Chaloupka FJ, eds. Tobacco control in developing countries. Oxford: Oxford University Press, 2000.

11 Farrelly MC, Bray JW, Office on Smoking and Health. Responses to Increases in cigarette prices by race/ethnicity, income, and age groups United States, 1976-1993. MMWR Morb Mortal Wkly Rep 1998;47:605-9.

12 Farrelly MC, Bray JW, Pechacek T, et al. "Response by adults to increases in cigarette prices by socioeconomic characteristics." Southern Economic Journal 2001;68:156-65

13 Becker GS, Murphy KM. "A theory of rational addiction. Journal of Political Economy 1988;96:675-700.

14 Becker GS, Grossman M, Murphy KM. An Empirical analysis of cigarette addiction. American Economic Review 1994;84:396-418.

15 Chaloupka FJ. Rational addictive behavior and cigarette smoking. Journal of Political Economy 1991;99:722-42.

16 Ligget \& Myers Inc. Interim report to stockholders, 3 months rnded March 31, 1969: report of annual meeting, April 29, 1969. R.J Reynolds Tobacco Company. April 29, 1969. Access date: December 3, 2001. Bates No. 500397668-500397690. URL: http:// www.rirtdocs.com/

17 Johnston ME. Economic forecast 1975-1980. Philip Morris Incorporated. March 3, 1975. Access date: December 3, 2001. Bates No. 1000739883-1000739907. URL: http://www.pmdocs.com/

18 Lyon HL, Spruill ML. A temporal cross-section analysis of cigarette price elasticity in the United States. Tobacco Merchants Association.
September 1977. Access date: December 3, 2001. Bates No. 502016148-502016154. URL: http://www.rirtdocs.com/

19 Policy Economics Group KPMG Peat Marwick. Analysis of cigarette price elasticities. Philip Morris USA. February 1990. Access date: December 3, 2001. Bates No. 2044982672-2044982689. URL: http://www.pmdocs.com/

20 Schneider L, Klein B, Murphy KM. Government regulation of cigarette health information. Journal of Law and Economics 1981;24:575-612.

21 Porter RH. The impact of government policy on the U.S. cigarette industry. In: Ippolito PM, Scheffman DT, eds. Empirical approaches to consumer protection economics. Washington DC: US Government Printing Office, 1986

22 Management Sciences Associates Inc. Total Industry shipment forecasts based on national price elasticity estimate. Philip Morris, U.S.A January 1991. Access date: December 3, 2001. Bates No. 2045522017-2045522038. URL: http://www.pmdocs.com/

23 Eibon J. California and New York excise tax increases. Philip Morris USA. November 3, 1989. Access date: December 3, 2001. Bates No. 2047937494-2047937508. URL: http://www.pmdocs.com/

24 Martin PG. Effect of California state tax increase on consumption per day, quitting rates and packings smoked, 1988-89 (1 st three quarters) Philip Morris USA. January 12, 1990. Access date: December 3, 2001 Bates No. 2045440173-2045440179. URL: http://www.pmdocs.com/ months after tax increase (MPID \#5549/294). Lorillard MPID. August 1994. Access date: December 3, 2001. Bates No. 82885447-82885550. URL: http://www.lorillarddocs.com/

26 The Roper Organization Inc. A study of public attitudes toward cigarette smoking and the tobacco industry in 1978: Volume 1. The Tobacco Institute. May 1978. Access date: December 3, 2001. Bates No. $501565967-501566019$. URL: http://www.rirtdocs.com/

27 Johnston $M$. Teenage smoking and the federal excise tax on cigarettes Philip Morris Inc. September 17, 1981. Access date: December 3, 2001. Bates No. 1000797544-1000797547. URL: http:// www.pmdocs.com/

28 Johnston M. The decline in the rate of growth of Marlboro Red. Philip Morris USA. May 21, 1975. Access date: December 3, 2001. Bates No. 1003285497-1003285502. URL: http://www.pmdocs.com/

29 Johnston M. Cigarette price elasticities and the implications for Philip Morris. Philip Morris USA. January 5, 1982. Access date: December 3 2001. Bates No. 2042790008-2042790014. URL: http:// www.pmdocs.com/

30 Lewit E, Coate D, Grossman M. The effect of government regulation on teenage smoking. Journal of Law and Economics 1981;24:545-69.

31 Lewit E, Coate D. The potential for using excise taxes to reduce smoking. Journal of Health Economics. 1982;1:101-16.

32 Johnston M. Smoking among high school seniors. Philip Morris USA. March 17, 1988. Access date: December 3, 2001. Bates No. 2022258815-2022258823. URL: http://www.pmdocs.com/

33 Johnston M. Price elasticity: Marlboro Red and other brands. Philip Morris USA. May 4, 1992. Access date: December 3, 2001 . Bates No. 2058122207-2058122209. URL: http://www.pmdocs.com/

34 Johnston $\boldsymbol{M}$. The effect of higher food prices on cigarette sales. Philip Morris USA. August 15, 1988. Access date: December 3, 2001. Bates No. 2022223338-2022223343. URL: http://www.pmdocs.com/

35 Burrows DS. NBER models of price sensitivity by age/Sex. R Reynolds Tobacco Co. October 6, 1982. Access date: December 3, 2001. Bates No. 503010298-503010299. URL: http://www.rirtdocs.com/

36 Burrows DS. Marketing implications of the NBER models. RJ Reynolds Tobacco Co. September 27, 1982. Access date: December 3, 2001. Bates No. $503011368-503011369$. URL: http://www.rirtdocs.com/

37 Hall LW. Action alternatives in a price-sensitive market. RJ Reynolds Tobacco Co. May 5, 1983. Access date: December 3, 2001. Bates No. 505250250-505250251. URL: http://www.rirtdocs.com/

38 Parham $\mathrm{MH}$. Evidence of price sensitivity among younger adult males. RJ Reynolds Tobacco Co. January 3, 1984. Access date: December 3, 2001. Bates No. 503981058. URL: http://www.rirtdocs.com/

39 Burrows DS. Young adult smokers: strategies and opportunities. RJ Reynolds Tobacco Company. February 29, 1984. Access date: December 3, 2001. Bates No. 501928462-501928550. URL: http://www.rirtdocs.com/

40 Exhibit I. Younger adult males demonstrate high interest (and rejection) in generic cigarettes. RJ Reynolds Tobacco Co. 1983. Access date: December 3, 2001. Bates No. 503981059-503981068. URL: http://www.rirtdocs.com/

41 RJ Reynolds. Younger adult smokers. RJ Reynolds Tobacco Co. 1988. Access date: December 3, 2001. Bates No. 506654883-506654969. URL: http://www.rirtdocs.com/

42 Benson SR. Price sensitivity by age. Lorillard Tobacco Company. March 20, 1992. Access date: December 3, 2001. Bates No. 82849666-82849667. URL: http://www.lorillarddocs.com/

43 Philip Morris. Pricing policy. Philip Morris. September 28, 1976. Access date: December 3, 2001. Bates No. 2023769635-2023769655. URL: http://www.pmdocs.com/ 44 Tobacco Reporter. Maxwell Tobacco Fact Book, 2000.

45 Johnston M. Handling an excise tax increase. Philip Morris USA September 3, 1987. Access date: December 3, 2001. Bates No. 2022216179-2022216180. URL: http://www.pmdocs.com/

46 Harris JE. The 1983 Increase in the federal cigarette excise tax. In: Summers LH, ed. Tax policy and the economy, volume 1. Cambridge, Massachusetts: MIT Press, 1987.

47 Johnston M. Price increases and cigarette sales - the Harris article. Philip Morris USA. July 15, 1987. Access date: December 3, 2001 Bates No. 2058122171-2058122172. URL: http://www.pmdocs.com/ 
48 RJ Reynolds. Pricing/tax statement. RJ Reynolds Tobacco Co. December 1, 1990. Access date: December 3, 2001. Bates No. 507473741. URL: http://www.rirtdocs.com/

49 RJ Reynolds. Project VB assessor analysis. RJ Reynolds Tobacco Co. May 1983. Access date: December 3, 2001. Bates No. 502068880-502068908. URL: http://www.rirtdocs.com/

50 RJ Reynolds. A qualitative study on project VB assessor. RJ Reynolds Tobacco Co. May 12, 1983. Access date: December 3, 2001. Bates No. 503013016-503013055. URL: http://www.rirtdocs.com/

51 Harden RJ. New business research and development report: project VB assessor analysis. RJ Reynolds Tobacco Co. June 2, 1983. Access date: December 3, 2001. Bates No. 502068771-502068808. URL: http://www.rirtdocs.com/

52 Philip Morris Companies Inc. PM new pricing and marketing program April 2, 1993. Access date: December 3, 2001. Bates No. 2048188736-2048188738. URL: http://www.pmdocs.com/

53 Grossman M, Chaloupka FJ. Cigarette taxes: the straw to break the camel's back. Public Health Reports 1997; 1 12:290-7.

54 Gruber J, Zinman J. Youth smoking in the United States: evidence and implications. In: Gruber J, ed. Risky behavior among youths: an economic analysis. Chicago: University of Chicago Press, 2001.

55 Philip Morris. Tobacco operations - primary questions. Philip Morris Companies Inc. April 10, 1995. Access date: December 3, 2001. Bates No. 2048537819-2048537870. URL: http://www.pmdocs.com/

56 Leo Burnett USA. Philip Morris USA Proposition 99: tobacco tax initiative California defense plan. Philip Morris USA. September 22, 1988. Access date: December 3, 2001. Bates No. 2048486666-2048486686. URL: http://www.pmdocs.com/

57 Leo Burnett USA. Philip Morris USA. New Jersey tobacco tax initiative defense media recommendation. July 9, 1990. Access date: December 3, 2001. Bates No. 2060295221-2060295232. URL: http://www.pmdocs.com/

58 Leo Burnett USA. New Jersey tobacco tax plan. Philip Morris USA. July 11, 1990. Access date: December 3, 2001. Bates No. 2060295219-2060295220. URL: http://www.pmdocs.com/

59 Slater S, Chaloupka FJ, Wakefield M. State variation in retail promotions and advertising for Marlboro cigarettes. Tobacco Contro $2001 ; 10: 337-9$
60 Shouse DW. 1987 federal excise tax increase. RJ Reynolds Tobacco Co. December 22, 1986. Access date: December 3, 2001. Bates No. 50676741 1-506767417. URL: http://www.rirtdocs.com/

61 Philip Morris. Tax increase. Tax relief. Get tax relief with this coupon. Enjoy our regular low price everyday. Philip Morris USA. 1991. Access date: December 3, 2001. Bates No. 2049033112. URL: http://www.pmdocs.com/

62 Philip Morris. Tax increase. Tax relief. Get tax relief with this coupon. Enjoy our regular low price everyday. Philip Morris USA. 1992. Access date: December 3, 2001. Bates No. 2049033132. URL http://www.pmdocs.com/

63 RJ Reynolds. Delaware joins FEDS in increasing cigarette taxes. Salem tax relief. The refreshest. Philip Morris Companies Inc. 1991. Access date: December 3, 2001. Bates No. 2040264594. URL: http://www.pmdocs.com/

64 Federal Trade Commission. Cigarette report for 1999. Washington DC: Federal Trade Commission, 2001.

65 Creighton FV. Camel growth among males 18-24 years old in the mid-west. RJ Reynolds Tobacco Co. July 25, 1986. Access date: December 3, 2001. Bates No. 505727418-505727431. URL: http://www.rirtdocs.com/

66 RJ Reynolds. Volume impact of Camel YAS growth. RJ Reynolds Tobacco Co. 1989. Access date: December 3, 2001. Bates No. 507181 150-507181 157. URL: http://www.rirtdocs.com/

67 Philip Morris. Marlboro new product development: PMUSA new products meeting. Richmond. Philip Morris USA. June 30, 1993. Access date: December 3, 2001. Bates No. 2021383397-2021383418. URL: http://www.pmdocs.com/

68 Saffer H. Tobacco advertising and promotion. In Jha P, Chaloupka FJ, eds. Tobacco control in developing countries. Oxford: Oxford University Press, 2000.

69 Saffer H, Chaloupka FJ. The effect of tobacco advertising bans on tobacco consumption. Journal of Health Economics 2000;1 19:1 117-37.

70 Wakefield $M$, Terry-McElrath YM, Chaloupka FJ, et al. "Tobacco industry marketing at the point-of-purchase after the 1998 MSA billboard advertising ban." Am J Public Health (in press)

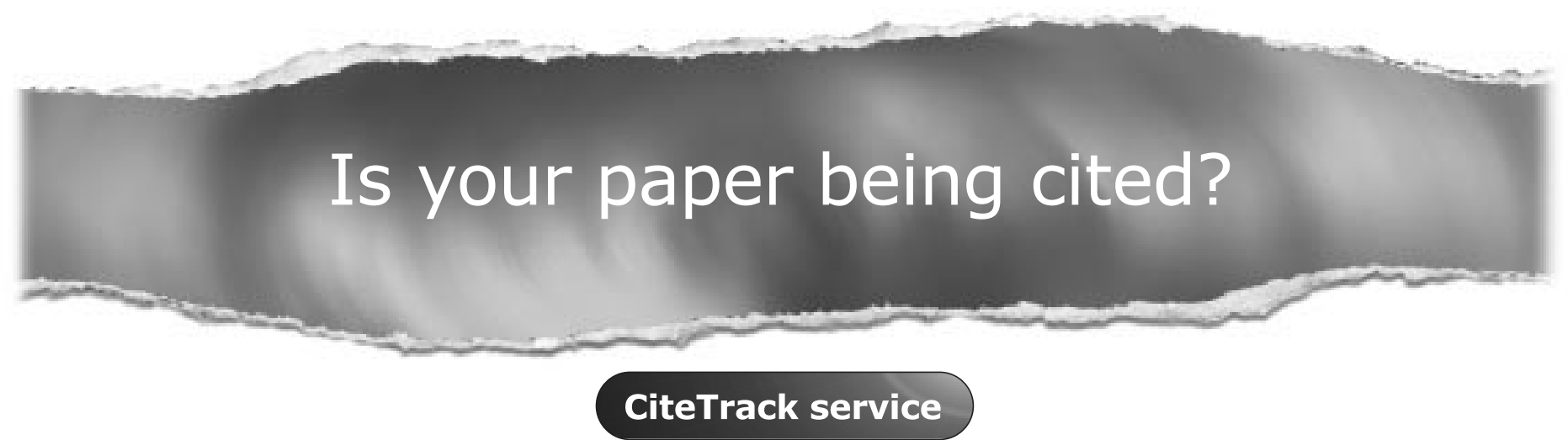

CiteTrack will alert you by email whenever new content in Tobacco Contro/ or a participating journal is published that matches criteria you want to track

Topics: Tell CiteTrack which words or subjects to watch for in new content Authors: Be alerted whenever key authors you are following publish a new paper Articles: Know whenever a paper of interest to you is referenced by another paper

\section{www.tobaccocontrol.com}

